\title{
A sand goby realizes its niche both at high population densities and in the presence of the half bridled goby
}

\author{
Craig A. Chargulaf*, Dana D. Burfeind, Ian R. Tibbetts \\ School of Biological Sciences, The University of Queensland, St Lucia, Queensland 4072, Australia
}

\begin{abstract}
To test theories of resource segregation and coexistence, we studied 2 goby species: the eastern sand goby Favonigobius lentiginosus (which typically occupies soft sediment tidepools) and the half-bridled goby Arenigobius frenatus (typically found in nearby subtidal seagrass beds). We used mesocosm experiments to test the hypotheses that (1) occupation of tidepools by $F$. lentiginosus is a function of exclusion (i.e. realized niche) from subtidal habitats by A. frenatus rather than habitat preference (i.e. fundamental niche) and (2) intraspecific competition among $F$. lentiginosus may also play a role in their occupation of intertidal pools. In single-species experiments, single specimens of both $A$. frenatus and $F$. lentiginosus spent significantly more time in the seagrass habitat. When together in the same mesocosm, F. lentiginosus significantly altered its habitat use to sand, while $A$. frenatus used more detritus habitat. At higher densities in singlespecies experiments with $F$. lentiginosus, a significantly greater number of individuals used the apparently less desirable sand habitat. Habitat preferences displayed by gobies in the laboratory setting did not directly reflect their distribution in their natural habitat, suggesting that the use of soft sediment tidepools by F. lentiginosus may be a consequence of competition with A. frenatus for space in seagrass beds, causing the former to occupy their realized niche of sandy habitat.
\end{abstract}

KEY WORDS: Soft sediment · Tidepools · Competition · Seagrass · Gobiidae

Resale or republication not permitted without written consent of the publisher

\section{INTRODUCTION}

The competitive exclusion principle suggests that for the stable coexistence of 2 or more species in a homogenous environment to occur, some form of niche differentiation between species is required (Volterra 1926, Lotka 1932), and species competing for the same resource cannot coexist (Hardin 1960). Coexistence of species can occur when the species use different resources, or partition the same resource either spatially or temporally (Nagelkerken et al. 2006). Density-mediated intraspecific interactions may promote coexistence by limiting the densities of the more aggressive competitor, keeping populations to low levels and allowing the less aggressive competitor to coexist (Stoll \& Prati 2001, Grether et al. 2009). On the other hand, the unified neutral theory of biodiversity and biogeography treats organisms as identical entities, predicting that biodiversity will reach an equilibrium between speciation and extinction that allows for a persistent distribution of relative species abundance (Hubbell 2001). This equilibrium may come at a cost to one of the species involved, which can be identified through comparing the fundamental and realized niche of interacting species.

The fundamental niche is influenced by the availability of resources, reproduction and environmental conditions, as well as the ecophysiological characteristics of a species (Arakaki \& Tokeshi 2011). By contrast, the realized niche is that which is occupied by a species that does not occupy its fundamental niche, usually due to avoidance of predation and competition (Hutchinson 1957, Sillero 2011). Some species may not occupy their fundamental niche due either 
to their historical separation or their limited ability to disperse to the preferred habitat (Holt 2003). Suitable habitats are a primary resource that must be shared or partitioned by co-occurring species, which is essential for species' coexistence (Schoener 1974, Rosenzweig 1981, Tokeshi 1999); however, this inevitably comes at a cost to the species that relinquishes its fundamental niche to occupy less favorable habitats (Sillero 2011).

Many fishes have shown preferences for a particular habitat type (Faria et al. 1998, Arakaki \& Tokeshi 2005, Fry et al. 2009). When planning reserves or taking other measures to conserve biodiversity, it is important to determine whether or not natural populations are actually either utilizing their preferred habitat or if they are merely occupying their realized niche. For instance, in aquaria, the code goby Gobiosoma robustum and the clown goby Microgobius gulosus prefer the same structured habitat when allopatric; however, in sympatry, $M$. gulosus occupies the less favorable sandy habitat, indicating that competition probably drives habitat use in the field (Schofield 2003). Interspecific competition has presumably driven the segregation of habitat use by intertidal triplefins (Trypterigidae), causing vertical zonation along the intertidal shore (Hilton et al. 2008).

In reef systems, the timing of the arrival of one species at a microhabitat may affect the ability of another species to colonize and survive (Geange \& Stier 2009). In extreme cases, dominant competitors may either force subordinates to use less optimal habitats (Holbrook \& Schmitt 2002) or displace them completely (Munday et al. 2002). Nevertheless, it has been suggested that interspecific competition may act as a structuring source for fish communities (Bonin et al. 2009). Although interspecific competition is common, coexistence can also occur, allowing for species to successfully cohabit a given area. A tank experiment with the round goby Neogobius melanostomus and the ruffe Gymnocephalus cernuus revealed that they prefer the same habitat either when alone or in sympatry and show no signs of interspecific competition (Bauer et al. 2007).

Intraspecific competition is another structuring force to which fish communities respond, particularly in density-dependent habitat selection, which can regulate populations (Morris 2003). At increased densities of conspecifics both halibut Hippoglossus stenolepis and the rock sole Lepidopsetta polyxystra show increased use of marginal habitats (Laurel et al. 2007). Spatial distribution of coral dwelling gobies is determined by the size of conspecifics, with larger individuals typically inhabiting larger corals (Hobbs
\& Munday 2004). It has even been suggested that intraspecific encounters are more aggressive than interspecific encounters because competitors are vying for the same resources (Mayr \& Berger 1992).

Gobies are the most diverse family of fishes in the world, and are small benthic-dwelling teleosts that occur in marine, estuarine and freshwater habitats (Choi \& Gushima 2002). They are also one of the more common permanent resident fishes of intertidal pools (Crowley \& Tibbetts 1995, Chotkowski et al. 1999, Meager et al. 2005, Chargulaf et al. 2011a) and seagrass beds (Jenkins et al. 1997, Franco et al. 2006, York et al. 2006). The benefits accruing from the occupation of intertidal pools may include extended access to intertidal food sources, reduced predation risk or enhanced growth rates from increased temperatures (Krück et al. 2009). Adjacent seagrass beds have similar functions including the provision of nursery habitat (Minello 1999, Beck et al. 2001, Heck et al. 2003), protection from predators (Stunz \& Minello 2001) and higher growth rates of associated nekton (Heck et al. 2003). The occupation of soft sediment pools by gobies drives them into competitive and predatory interaction with the commercially important sand whiting Sillago ciliata, which is thought to primarily use sand pools as a nursery habitat (Krück et al. 2009).

The sheltered littoral habitats of Moreton Bay, Australia, support persistent and widespread populations of the eastern sand goby Favonigobius lentiginosus in soft sediment intertidal pools, while the halfbridled goby Arenigobius frenatus is typically found in nearby subtidal seagrass beds (Chargulaf 2010). The present study had 2 principal objectives: (1) to determine whether occupation of tidepools by $F$. lentiginosus is a function of habitat preference (i.e. fundamental niche) or exclusion (i.e. realized niche) from subtidal habitats by $A$. frenatus; and (2) to determine if intraspecific competition amongst $F$. lentiginosus may also play a role in their occupation of intertidal pools with high densities in their fundamental niche, forcing individuals to occupy their realized niche. We hypothesized that fish would utilize more structural habitats (i.e. seagrass) when alone and tend to move to less favorable habitats in the presence of a potential competitor.

\section{MATERIALS AND METHODS}

\section{Experimental mesocosms}

To mimic the available intertidal habitat of the shore at Dunwich, Queensland $\left(27^{\circ} 40^{\prime} \mathrm{S}, 153^{\circ} 40^{\prime} \mathrm{E}\right)$, 
we created unvegetated substrate (sand), seagrass (Zostera muelleri), detritus (consisting of mangrove leaves, dead seagrass and small woody debris) and bare areas in plastic experimental mesocosms (length $\times$ width $\times$ depth: $25 \times 40 \times 25 \mathrm{~cm}$ ). Sand, seagrass and detritus are commonly found on the intertidal shores where the experimental species were sourced, and bare habitat was chosen as a control as it would be expected to be the least occupied space, except in unfavorable conditions. Habitat types were located in each quarter of each mesocosm (i.e. $6.25 \times$ $10 \times 6.25 \mathrm{~cm}$ per habitat) and the mesocosm was filled with $15 \mathrm{l}$ of seawater at $35 \mathrm{ppt}$ and maintained between 23 and $26^{\circ} \mathrm{C}$, aerated by bubblers. Mesocosms were established $48 \mathrm{~h}$ prior to commencing the first trial. Fifteen units were set up and habitat placement was random. All habitats were derived from materials obtained from the sandflats near Dunwich.

Because the objective of the experiment was to examine habitat preference and interference competition, all habitat types were cleared of food sources. Sand and detritus were washed thoroughly with fresh water and dried. Seagrass was first cleaned by washing off sediment and removing epiphytes from the blades (as per Burfeind et al. 2009), and then replanted in densities similar to those found in tidepools at Dunwich.

\section{Interference competition trials}

Gobies were collected from sandflats and seagrass beds adjacent to Dunwich, Queensland. Favonigobius lentiginosus were collected from tidepools using dip nets, and Arenigobius frenatus were collected using an $8 \times 1.5 \mathrm{~m}$ seine net $(2 \mathrm{~mm}$ mesh) in the adjacent seagrass beds. Tidepools were typically ephemeral depressions on a sandy beach formed by stingrays foraging in the sediment. A total of 60 F. lentiginosus and $30 \mathrm{~A}$. frenatus were caught for the experiment. Fish were immediately taken to the Moreton Bay Research Station and held in aerated aquaria. Before being placed into the aquaria, fish were measured to standard length $( \pm 1.0 \mathrm{~mm})$ with dial calipers and separated into adult size classes $15-19,20-24,25-29$ and $30-35 \mathrm{~mm}$ to reduce the influence of size differences as a factor in the trials. For the density trials and competition trials, only fish of the same size class were used in each aquarium. Experimental mesocosms were held in the laboratory for the duration of the experiment. Fish were fed daily with a mixture of live shrimp and frozen brine shrimp in between trials.
To determine habitat preference for each species, one randomly selected goby was initially placed in the centre of each of the 15 experimental mesocosms. Fish were allowed to acclimate for $2 \mathrm{~h}$. The location of each fish was observed every $3 \mathrm{~h}$ for $24 \mathrm{~h}$ to determine the percentage of habitat use. Percent occurrence of fish in each habitat type was measured during the day and night to measure habitat use and the percentage was averaged over the $24 \mathrm{~h}$ period. After the trial, fish were returned to their holding aquaria and a random set of 15 selected individuals (potentially including former individuals used in previous trials) were placed into experimental mesocosms for a total of 45 replicates of each species. During nocturnal observations, overhead lights remained off and fish were located with a red LED light to minimize disturbance.

To determine whether competition had any effect on habitat preference, 2 fish (one of each species) were placed into the experimental mesocosms. Trials were performed as described above for a total of 45 replicates.

\section{Density-dependent competition trials}

The same mesocosm configuration was used to test density effects on habitat use. Density was only tested on Favonigobius lentiginosus, due to the small numbers of Arenigobius frenatus caught. Densities of 4, 6 and 12 individuals per tank were used, and trials were run as with the individual gobies. Individuals in each tank were from the same size class to eliminate the influence of size in determining habitat preference. The positions of all fish were recorded every $3 \mathrm{~h}$ over a $24 \mathrm{~h}$ period to determine the number of individuals of each species in each habitat. Following each trial, all gobies were returned to their holding aquarium and new individuals (potentially including former individuals used in previous trials) were randomly selected by size class for subsequent trials.

\section{Statistical analysis}

For trials with 1 individual of each species per tank (i.e. to assess the interference competition between the 2 species), chi-square tests were used to compare individual species habitat occupation when alone and when with the potential competitor. Habitat preferences as a function of changing fish density of Favonigobius lentiginosus were analyzed with a 2-way ANOVA followed by post hoc Bonferroni tests 

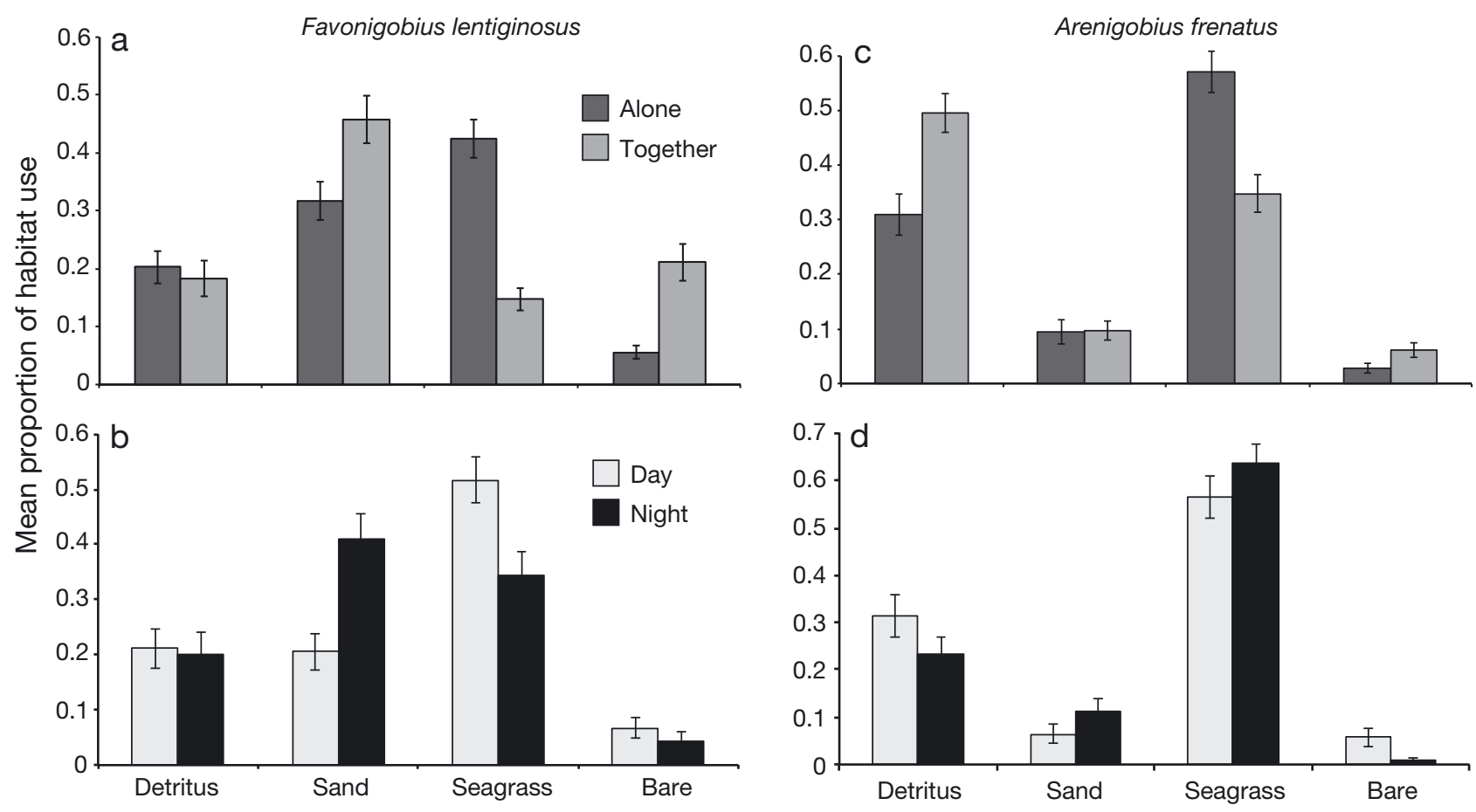

Substrate

Fig. 1. Favonigobius lentiginosus, Arenigobius frenatus. Mean $( \pm \mathrm{SE}, \mathrm{n}=45$ replicates) proportion of habitat use by 2 goby species in a mesocosm experiment with detritus, sand, seagrass and bare substrates. Habitat use by individual (a,b) sand gobies or $(c, d)$ seagrass gobies when $(a, c)$ alone or in the presence of a potential competitor, i.e an individual of the other goby species; or (b,d) during day- vs. night-time (1 goby per tank)

comparing habitat use with the density of fish. Prior to all analyses, the proportion of fish choosing a habitat in each trial was normalized via log transformation, which was required as the data was not considered to be independent (Aitchison 1982). These analyses were conducted using Statistica version 7.1.

\section{RESULTS}

Favonigobius lentiginosus, when alone, preferred the seagrass habitat to detritus and bare habitats (chi-square, $\mathrm{p}=0.001$ and $\mathrm{p}<0.001$, respectively) (Fig. 1a). The proportion of seagrass and sand habitat use was not significantly different (chi-square, $p=$ 0.07 ), nor was the proportion of sand and detritus habitat use (chi-square, $p=0.138$ ). There was a significant difference in the proportion of habitat use between day and night, with more sand habitat and less seagrass habitat being used at night (Fig. 1b). Arenigobius frenatus, when alone, also preferred the seagrass habitat to all other habitats (chi-square, $\mathrm{p}<$ 0.05 for all tests) (Fig. 1c). The use of sand and bare substrate was not significantly different (chi-square, $p=0.17$ ); however, all other comparisons were signif- icant (chi-square, $\mathrm{p}<0.05$ for all tests). There was no significant difference in proportion of habitat use between day and night for any habitat (chi-square, $\mathrm{p}>0.05$ for all tests) (Fig. 1d).

Chi-square tests revealed several significant differences for the interference competition trials, most notably the use of habitats by Favonigobius lentiginosus in the presence of Arenigobius frenatus (Table 1). When in the same tank as A. frenatus, use of seagrass habitat by $F$. lentiginosus significantly

Table 1. Favonigobius lentiginosus and Arenigobius frenatus. Chi-square results comparing habitat occupation by the sand goby $F$. lentiginosus and seagrass goby A. frenatus in a mesocosm experiment when alone and when paired with a potential competitor, i.e. an individual of the other species

\begin{tabular}{|llrr|}
\hline Species & Habitat & $\chi^{2}$ & \multicolumn{1}{c|}{$\mathrm{p}$} \\
\hline F. lentiginosus & Detritus & 10.11 & 0.120 \\
& Sand & 12.92 & 0.115 \\
& Seagrass & 37.38 & $<0.001$ \\
& Bare & 19.20 & 0.004 \\
A. frenatus & Detritus & 16.37 & 0.037 \\
& Sand & 4.78 & 0.444 \\
& Seagrass & 20.00 & 0.010 \\
& Bare & 4.11 & 0.250 \\
\hline
\end{tabular}


decreased, and use of bare habitat significantly increased, while its uses of sand and detritus were not significantly different (Fig. 1a, Table 1). There was a significant difference in habitat use by $A$. frenatus in the presence of $F$. lentiginosus with a decrease in seagrass and an increase in detritus habitat use, while there was no significant difference between sand and bare habitat usage (Fig. 1c, Table 1).

Density of Favonigobius lentiginosus significantly influenced habitat use (ANOVA, $\mathrm{F}_{9,176}=7.67, \mathrm{p}<$ 0.0001 ) with a greater number of individuals occupying the bare and detritus habitats at higher densities (Fig. 2). Habitat use was significantly different for bare habitat between densities of 1 and 12 individuals (Bonferroni, $\mathrm{p}<0.0001$ ), and for detritus habitat between densities of 1 and 6 (Bonferroni, p < 0.032) with a higher proportion of use at higher densities. Habitat use was not significantly different between densities of 4 and 6 individuals for any habitat (Bonferroni, $p \geq 0.05$ for all tests). The use of the sand habitat did not differ significantly among density levels (Bonferroni, p > 0.05), while seagrass use significantly decreased as fish densities increased (Bonferroni, $\mathrm{p}<0.05$ for all tests).

\section{DISCUSSION}

Markedly different habitat selection patterns occur in laboratory mesocosms when gobies are sole occupants than when they share habitat with a potential competitor. Individuals of Favonigobius

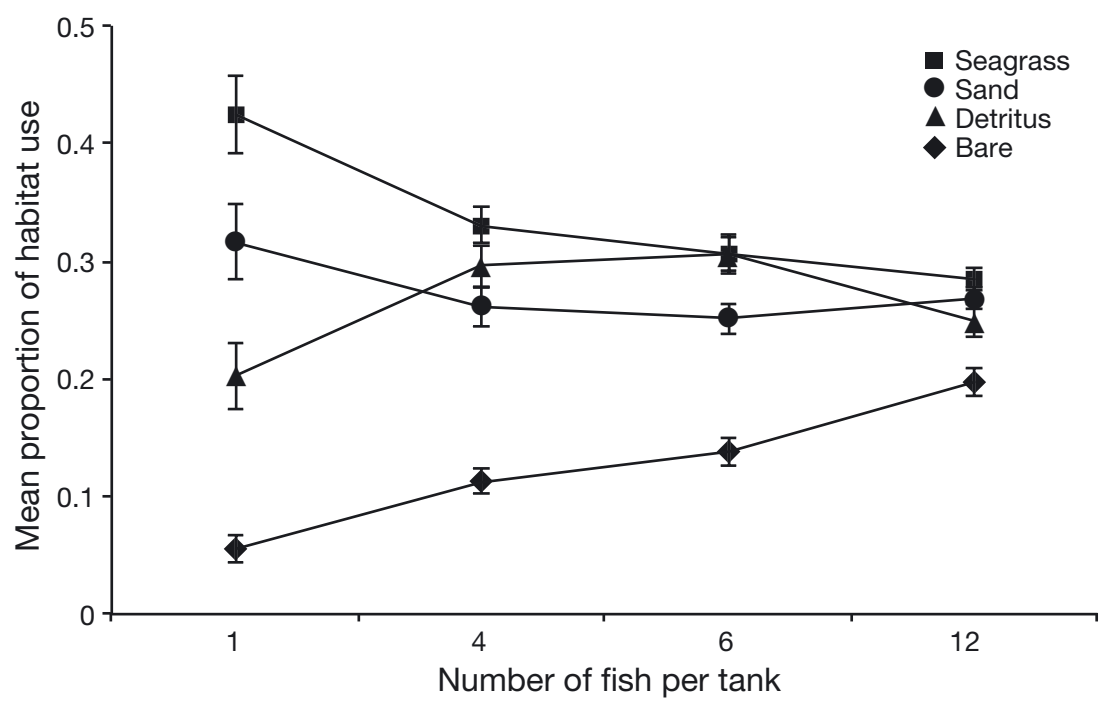

Fig. 2. Favonigobius lentiginosus. Average percent usage $( \pm \mathrm{SE})$ of different substrates by the sand goby at increasing densities $(1,4,6$ and 12 gobies per tank): $(\boldsymbol{\Delta})$ detritus, $(\mathbf{\bullet})$ sand, $(\boldsymbol{\square})$ seagrass, $(\diamond)$ bare substrate. $\mathrm{n}=45$ replicates per density group lentiginosus and Arenigobius frenatus both preferred the seagrass habitat, but in the presence of one another, both species reduced their use of seagrass habitat and increased the use of other, presumably less desirable habitats. This suggests that the use by $F$. lentiginosus of sandflat tidepools may be a result of interference competition for space in the adjacent seagrass beds and that the use of sandy soft-sediment tidepools in situ may be $F$. lentiginosus' realized niche. This is similar to the relationship between the gobies Pomatoschistus microps and Gobius niger, where G. niger appears to drive $P$. microps from its preferred vegetated habitat, most likely because G. niger is larger (Wiederholm 1987). The gobies used in our trials were all of a similar size, yet the same pattern of displacement appeared to be occurring, presumably due to more aggressive behavior displayed by $A$. frenatus, as this species was observed chasing individuals of $F$. lentiginosus in some of the mesocosms. However, A. frenatus also displayed some minor displacement, suggesting that limiting contact is preferred over potentially aggressive encounters. In the Baltic Sea, the round goby Neogobius melanostomus may have a negative effect on the flounder Platichthys flesus, by restricting the flounder's utilization of preferred habitat, but the round goby may have also had an impact on the flounder due to diet overlap (Karlson et al. 2007). The round goby has also been shown to displace native logperch Percina caprodes and mottled sculpin Cottus bairdi in the Great Lakes due to competition for habitable space (Janssen \& Jude 2001, Balshine et al. 2005). In the case of $A$. frenatus and $F$. lentiginosus, both species alter habitat use patterns when in close proximity, indicating that avoidance of negative interactions may take priority over preferred habitat use.

Some gobiids can coexist with other cohabitants. For example, the giant goby Gobius cobitis prefers sandy substrata when in both monoand heterospecific groups (Faria et al. 1998). Coexistence between the Eurasian ruffe Gymnocephalus cernuus and round gobies was detected by Bauer et al. (2007) who found that substrate preference is not affected by the presence of a potential competitor. However, our study suggests that 2 gobies in Moreton Bay are 
poor cohabitants when held in proximity, which might explain their segregation in the wild.

High densities of Favonigobius lentiginosus also affect distribution amongst the different habitat types. As hypothesized, gobies started using suboptimal habitats (i.e. bare plastic) as the density of gobies increased. Increased use of suboptimal habitats at greater densities suggests that the benefit that might accrue from access to the preferred habitat is being compromised (Laurel et al. 2007). Male round gobies are known to prefer rocky habitats, but when densities get too high they will start using other habitats (Bergstrom et al. 2008). Density-dependent habitat competition in the European bullhead Cottus gobio, a member of the sculpin family, only occurs between juveniles and adults, with juveniles being displaced to the marginal habitats (Davey et al. 2005); however, competition between different size classes and age groups was not tested in our experiments. Individual species habitat selection is seemingly closely related to population regulation and the persistence of populations over time where population growth rates reach an equilibrium based on the quality of habitat occupied (Morris 2003). Thus, F. lentiginosus is likely to have a threshold density above which migration to other potential habitats occurs in order to limit intraspecific interference competition.

Our experiments suggest that competition between gobies drives habitat segregation, rather than habitat preference acting alone. Preferences for microhabitats have been used to explain the distribution of gobiid fishes in Japanese tidepools, where 3 species minimize competition by selecting particular substrates within a pool (Arakaki \& Tokeshi 2005). However, the preference for seagrass by both gobiids in the present study suggests that they may be directly competing for the same fundamental resource or that the species rarely overlap in the field due to historical niche differentiation. Gobiidae are usually the most common and the most abundant fish found occupying intertidal shores (Meager et al. 2005). While typically more than one species is found in a particular habitat, one of the goby species tends to dominate the assemblage (Ford et al. 2004), which may indicate interference competition for habitable space is having an influence on fish assemblages in soft sediment tidepools.

An understanding of habitat selection is important for both behavioral ecology and conservation biology, and resource availability has been considered one of the most important components in the selection of particular habitats by animals (Wolf et al. 2009). Intertidal habitat selection by gobies is proba- bly not driven by resource availability, as the abundances of benthic prey are typically robust and persistent (Coull 1999), as is the case for soft sediment tidepools in Moreton Bay (authors' unpubl. data). Both of our study species forage on benthic invertebrates, with Favonigobius lentiginosus preferring benthic copepods and decapod shrimp (Chargulaf et al. 2011b); however, diet preferences of Arenigobius frenatus are not known.

Most fundamental ecological theories of population dynamics and species coexistence are based on the principle that individuals are negatively affected by the density of either conspecifics or heterospecifics, which has been shown in mammals (Eccard \& Ylönen 2007), insects (Bográn et al. 2002) and birds (Mezquida et al. 2005), as well as fish (Bergstrom et al. 2008). Our experiments also highlight the potential negative effects of competition for a shared preferred habitat, with Favonigobius lentiginosus apparently being displaced from their fundamental niche; however, the results here may also be due to differences in optimal diets, physical capabilities of each species to deal with subtidal habitats or historical niche differentiation. In some cases, coexistence and high densities can provide benefits. For example, the population densities at roosting habitats of 2 species of arboreal migratory birds were positively correlated, which may have occured because the greater abundances of one species were indicative of good quality habitat to the other species (Forsman et al. 2009). Pusenius et al. (2000) suggest that habitat preferences of voles are driven by familiarity with an area, in order increase foraging effectiveness and reduce predation risk. Such familiarity could explain why $F$. lentiginosus occupies the intertidal sandflats and soft sediment tidepools. Higher densities of surgeonfish on coral reefs were suggested to increase foraging efficiency by diluting aggressive attacks from competitors (Lawson et al. 1999). It is possible that $F$. lentiginosus has adapted to the less optimal sandy habitat, and the higher densities are reducing competition from Arenigobius frenatus in the intertidal zone.

More importantly, the competitive interactions that result in habitat exclusions may be important drivers of evolutionary processes at small scales. When occupying separate niches in a geographic area, divergent speciation may occur and habitat isolation may evolve as a result (Rundle \& Nosil 2005). While the Gobiidae is the largest family of fishes, its members differ little morphologically, typically being benthic and only a few species being pelagic. The interference competition for habitable space observed in 
this experiment may explain the divergence of Favonigobius lentiginosus from seagrass to soft sediment intertidal pools and point to this process as a significant contributor to the diversification in this fish family.

Acknowledgements. This experiment was partially funded by the Moreton Bay Community Research Scholarship. We thank the staff of the Moreton Bay Research Station for providing space and accommodation. We also thank Christine Buckius and Justin Large for assistance with mesocosm set up and goby collection. The authors also thank the anonymous reviewers that helped improve this manuscript. This work was conducted under University of Queensland Animal Ethics Committee approval number CMS/130/07/UQ.

\section{LITERATURE CITED}

Aitchison J (1982) The statistical analysis of compositional data. J Roy Stat Soc B Met 44:139-177

> Arakaki S, Tokeshi M (2005) Microhabitat selection in intertidal gobiid fishes: species- and size-associated variation. Mar Biol Res 1:39-47

Arakaki S, Tokeshi M (2011) Analysis of spatial niche structure in coexisting tidepool fishes: null models based on multi-scale experiments. J Anim Ecol 80:137-147

Balshine S, Verma A, Chant V, Theysmeyer T (2005) Competitive interactions between round gobies and logperch. J Gt Lakes Res 31:68-77

> Bauer CR, Bobeldyk AM, Lamberti GA (2007) Predicting habitat use and trophic interactions of Eurasian ruffe, round gobies, and zebra mussels in nearshore areas of the Great Lakes. Biol Invasions 9:667-678

> Beck MW, Heck KL, Able KW, Childers DL and others (2001) The identification, conservation, and management of estuarine and marine nurseries for fish and invertebrates. Bioscience 51:633-641

> Bergstrom MA, Evrard LM, Mensinger AF (2008) Distribution, abundance, and range of the round goby, Apollonia melanostoma, in the Duluth-Superior Harbor and St. Louis River Estuary, 1998-2004. J Gt Lakes Res 34: 535-543

Bográn CE, Heinz KM, Ciomperlik MA (2002) Interspecific competition among insect parasitoids: field experiments with whiteflies as hosts in cotton. Ecology 83:653-668

Bonin MC, Srinivasan M, Almany GR, Jones GP (2009) Interactive effects of interspecific competition and microhabitat on early post-settlement survival in a coral reef fish. Coral Reefs 28:265-274

Burfeind DD, Tibbetts IR, Udy JW (2009) Habitat preference of three common fishes for seagrass, Caulerpa taxifolia, and unvegetated substrate in Moreton Bay, Australia. Environ Biol Fishes 84:317-322

Chargulaf CA (2010) The ecology of soft sediment tidepool dwelling gobies (Pisces: Gobiidae) in Moreton Bay, Australia. PhD dissertation, The University of Queensland, St. Lucia

> Chargulaf CA, Townsend KA, Tibbetts IR (2011a) Community structure of soft sediment pool fishes in Moreton Bay, Australia. J Fish Biol 78:479-494

> Chargulaf CA, Krück NC, Tibbetts IR (2011b) Does sympatry affect trophic resource use in congeneric tidepool fishes? A tale of two gobies Favonigobius lentiginosus and Favonigobius exquisitus. J Fish Biol 79:1968-1983

Choi SH, Gushima K (2002) Spot-fixed fin digging behavior in foraging of the benthophagous maiden goby, Pterogobius virgo (Perciformes: Gobiidae). Ichthyol Res 49: 286-290

Chotkowski MA, Buth DG, Prochazka K (1999) Systematics of intertidal fishes. In: Horn MH, Martin KLM, Chotkowski MA (eds) Intertidal fishes: life in two worlds. Academic Press, San Diego, CA, p 297-331

Coull BC (1999) Role of meiofauna in estuarine soft-bottom habitats. Aust J Ecol 24:327-343

Crowley BG, Tibbetts IR (1995) The diversity of fishes inhabiting bare intertidal pools on two sedimentary shores in Moreton Bay. Proc R Soc Queensland 105:21

Davey AJH, Hawkins SJ, Turner GF, Doncaster CP (2005) Size dependent microhabitat use and intraspecific competition in Cottus gobio. J Fish Biol 67:428-443

Eccard JA, Ylönen H (2007) Costs of coexistence along a gradient of competitor densities: an experiment with arvicoline rodents. J Anim Ecol 76:65-71

Faria C, Almada V, Nunes MD (1998) Patterns of agnostic behaviour, shelter occupation and habitat preference in juvenile Lipophrys pholis, Coryphoblennius galerita and Gobius cobitis. J Fish Biol 53:1263-1273

Ford JMJ, Tibbetts IR, Carseldine L (2004) Ventilation rate and behavioural responses of two species of intertidal goby (Pisces: Gobiidae) at extremes of environmental temperature. Hydrobiologia 528:63-73

Forsman JT, Hjernquist MB, Gustafsson L (2009) Experimental evidence for the use of density based interspecific social information in forest birds. Ecography 32:539-545

- Franco A, Franzoi P, Malavasi S, Riccato F, Torricelli P, Mainardi D (2006) Use of shallow water habitats by fish assemblages in a Mediterranean coastal lagoon. Estuar Coast Shelf Sci 66:67-83

Fry G, Milton DA, Van Der Velde T, Stobutzki I, Andamari R, Badrudin, Sumiono B (2009) Reproductive dynamics and nursery habitat preferences of two commercially important Indo-Pacific red snappers Lutjanus erythropterus and L. malabaricus. Fish Sci 75:145-158

> Geange SW, Stier AC (2009) Order of arrival affects competition in two reef fishes. Ecology 90:2868-2878

Grether GF, Losin N, Anderson CN, Okamoto K (2009) The role of interspecific interference competition in character displacement and the evolution of competitor recognition. Biol Rev Camb Philos Soc 84:617-635

> Hardin G (1960) Competitive exclusion principle. Science 131:1292-1297

> Heck KL, Hays G, Orth RJ (2003) Critical evaluation of the nursery role hypothesis for seagrass meadows. Mar Ecol Prog Ser 253:123-136

> Hilton Z, Wellenreuther M, Clements KD (2008) Physiology underpins habitat partitioning in a sympatric sister-species pair of intertidal fishes. Funct Ecol 22:1108-1117

> Hobbs JPA, Munday PL (2004) Intraspecific competition controls spatial distribution and social organisation of the coral-dwelling goby Gobiodon histrio. Mar Ecol Prog Ser 278:253-259

> Holbrook SJ, Schmitt RJ (2002) Competition for shelter space causes density-dependant predation mortality in damselfishes. Ecology 83:2855-2868

Holt RD (2003) On the evolutionary ecology of species' ranges. Evol Ecol Res 5:159-178

Hubbell SP (2001) The unified neutral theory of biodiversity 
and biogeography. Princeton University Press, Princeton, NJ

Hutchinson GE (1957) Concluding remarks. Cold Spring Harb Symp Quant Biol 22:415-427

> Janssen J, Jude DJ (2001) Recruitment failure of mottled sculpin Cottus bairdi in Calumet Harbor, southern Lake Michigan, induced by the newly introduced round goby Neogobius melanostomus. J Gt Lakes Res 27:319-328

> Jenkins GP, May HMA, Wheatley MJ, Holloway MG (1997) Comparison of fish assemblages associated with seagrass and adjacent unvegetated habitats of Port Phillip Bay and Corner Inlet, Victoria, Australia, with emphasis on commercial species. Estuar Coast Shelf Sci 44: 569-588

Karlson AM, Almqvist G, Skóra KE, Appelberg M (2007) Indication of competition between the non-indigenous round goby and native flounder in the Baltic Sea. ICES J Mar Sci 64:479-486

Krück NC, Chargulaf CA, Saint-Paul U, Tibbetts IR (2009) Early post-settlement habitat and diet shifts and the nursery function of tidepools during Sillago spp. recruitment in Moreton Bay, Australia. Mar Ecol Prog Ser 384: 207-219

Laurel BJ, Stoner AW, Hurst TP (2007) Density-dependent habitat selection in marine flatfish: the dynamic role of ontogeny and temperature. Mar Ecol Prog Ser 338: 183-192

Lawson GL, Kramer DL, Hunte W (1999) Size-related habitat use and schooling behavior in two species of surgeonfish (Acanthurus bahianus and A. coeruleus) on a fringing reef in Barbados, West Indies. Environ Biol Fishes 54:19-33

Lotka AJ (1932) Contribution to the mathematical theory of capture. I. Conditions for capture. Proc Natl Acad Sci USA 18:172-178

Mayr M, Berger A (1992) Territoriality and microhabitat selection in two intertidal New Zealand fish. J Fish Biol 40:243-256

Meager JJ, Williamson I, King CR (2005) Factors affecting the distribution, abundance and diversity of fishes of small, soft-substrata tidal pools within Moreton Bay, Australia. Hydrobiologia 537:71-80

Mezquida ET, Villarán A, Pasqual-Parra J (2005) Microhabitat use and social structure in linnet Carduelis cannabina and corn bunting Miliaria calandra at a winter roost in central Spain. Bird Study 52:323-329

Minello TJ (1999) Nekton densities in shallow estuarine habitats of Texas and Louisiana and the identification of essential fish habitat. In: Benaka L (ed) Fish habitat: essential fish habitat, and rehabilitation. American Fish-

Editorial responsibility: Charles Birkeland,

Honolulu, Hawaii, USA eries Society, Bethesda, MD, p 43-75

> Morris DW (2003) Toward an ecological synthesis: a case for habitat selection. Oecologia 136:1-13

> Munday PL, Pierce SJ, Jones GP, Larson HK (2002) Habitat use, social organization and reproductive biology of the seawhip goby, Bryaninops yongei. Mar Freshw Res 53: 769-775

- Nagelkerken I, van der Velde G, Verberk W, Dorenbosch M (2006) Segregation along multiple resource axes in a tropical seagrass fish community. Mar Ecol Prog Ser 308: 79-89

Pusenius J, Ostfeld RS, Keesing F (2000) Patch selection and tree-seedling predation by resident versus immigrant meadow voles. Ecology 81:2951-2956

Rosenzweig ML (1981) A theory of habitat selection. Ecology 62:327-335

> Rundle HD, Nosil P (2005) Ecological speciation. Ecol Lett 8: 336-352

Schofield PJ (2003) Habitat selection of two gobies (Microgobius gulosus, Gobiosoma robustum): influence of structural complexity, competitive interactions, and presence of a predator. J Exp Mar Biol Ecol 288:125-137

> Schoener TW (1974) Resource partitioning in ecological communities. Science 185:27-39

Sillero N (2011) What does ecological modeling model? A proposed classification of ecological niche models based on their underlying methods. Ecol Model 222:1343-1346

Stoll P, Prati D (2001) Intraspecific aggregation alters competitive interactions in experimental plant communities. Ecology 82:319-327

> Stunz GW, Minello TJ (2001) Habitat-related predation on juvenile wild-caught and hatchery-reared red drum Sciaenops ocellatus (Linnaeus). J Exp Mar Biol Ecol 260: 13-25

Tokeshi M (1999) Species coexistence: ecological and evolutionary perspective. Blackwell Science, Oxford

- Volterra V (1926) Fluctuations in the abundance of a species considered mathematically. Nature 118:558-560

Wiederholm AM (1987) Habitat selection and interactions between three marine fish species (Gobiidae). Oikos 48: 28-32

Wolf M, Frair J, Merrill E, Turchin P (2009) The attraction of the known: the importance of spatial familiarity in habitat selection in wapiti Cervus elaphus. Ecography 32: 401-410

York PH, Booth DJ, Glasby TM, Pease BC (2006) Fish assemblages in habitats dominated by Caulerpa taxifolia and native seagrasses in south-eastern Australia. Mar Ecol Prog Ser 312:223-234

Submitted: September 21, 2012; Accepted: May 31, 2013

Proofs received from author(s): August 7, 2013 